\title{
EVALUASI EFEKTIVITAS DAN EFISIENSI SISTEM INFORMASI OPERASIONAL MENGGUNAKAN METODE COST BENEFIT ANALYSIS: STUDI KASUS PADA RESTAURANT SEA FOOD DI JAKARTA
}

\author{
Lianawati Christian; Ribka Rosalina; Melissa; Rosalia \\ Computerized Accounting Department, School of Information Systems, Binus University \\ Jl. K.H. Syahdan No. 9, Palmerah, Jakarta Barat 11480 \\ Liana_ch1309@binus.ac.id
}

\begin{abstract}
This study aims to identify whether the information system used by a sea food restaurant has been efficient and effective. It can support decision making for follow-up actions. The methodology used in this study is literature study, interview, and survey. To evaluate the effectiveness of operational information systems at the restaurant, we use cost benefit analysis. To evaluate whether the operational information system is efficient, we use questionnaire with Likert scale calculations. Based on the evaluation of the effectiveness and efficiency of operational information system at the restaurant, it can be seen there is a difference between investment in 20042009 and investment in 2010. From the results of calculation using cost benefit analysis to determine the effectiveness, we find that investment in 2004 was positive while investment in 2010 is still negative. Based on the results of questionnaires, the investments are considered efficient. Based on the evaluation, information systems used in sea food restaurant has been effective and efficient. The return on investment only takes less than two years and the information systems supports operational activities.
\end{abstract}

Keywords: evaluation, effectiveness, efficiency, information systems, cost benefit analysis

\begin{abstract}
ABSTRAK
Penelitian ini bertujuan untuk mengetahui apakah sistem informasi yang digunakan oleh sebuah restaurant sea food yang bernama Bandar Djakarta telah efisien dan efektif. Penelitian ini dapat membantu pengambilan keputusan mengenai tindak lanjut ke depan bagi perusahaan. Tindak lanjutnya dapat berupa pengembangan kembali apabila sudah efektif dan efisien. Metode yang digunakan dalam penelitian ini berupa studi pustaka, wawancara, dan survei. Untuk mengevaluasi efektifitas sistem informasi operasional pada restaurant tersebut, kami menggunakan metode cost benefit analysis. Untuk mengevaluasi apakah sistem informasi operasionalnya efisien, kami menggunakan kuisioner dengan perhitungan skala likert. Berdasarkan hasil evaluasi efektivitas dan efisiensi sistem informasi operasional pada restaurant tersebut dapat dilihat terdapat perbedaan antara investasi tahun 2004-2009 dan investasi tahun 2010. Dari hasil perhitungan menggunakan metode cost benefit analysis untuk mengetahui efektivitas, didapatkan bahwa investasi tahun 2004 adalah positif sedangkan pada tahun 2010 masih negatif. Serta berdasarkan hasil kuisioner, investasi yang dilakukan sudah efisien. Berdasarkan hasil evaluasi, sistem informasi yang digunakan pada restaurant sea food tersebut telah efektif dan efisien. Terlihat pengembalian investasi hanya membutuhkan waktu tidak lebih dari dua tahun dan sistem informasi telah mendukung kegiatan operasional.
\end{abstract}

Kata kunci: evaluasi, efektivitas, efisiensi, sistem informasi, cost benefit analysis 


\section{PENDAHULUAN}

Teknologi informasi pada umumnya lebih banyak bersifat intangible benefit daripada tangible benefit. Tangible benefit merupakan keuntungan yang berupa penghematan atau peningkatan di dalam perusahaan yang dapat diukur secara kuantitas dalam bentuk satuan nilai uang, sedangkan intangible benefit adalah keuntungan-keuntungan yang sulit atau tidak mungkin diukur dalam bentuk satuan nilai uang. Bandi (2006) berpendapat bahwa teknologi informasi memungkinkan perusahaan yang mengadopsinya memiliki keunggulan kompetitif. teknologi informasi memberikan peluang bagi perusahaan untuk meningkatkan koordinasi dan pengendalian, atau dapat pula dimanfaatkan untuk mendapatkan keunggulan daya saing di pasar dunia.

Fitzpatrick (2005) menyatakan, "An IT investment consists of the total life cycle cost of an entire project or project chunk that involves IT, including the post-project operating cost of the system that was implemented". Definisi tersebut dapat diartikan investasi teknologi informasi terdiri total biaya life cycle dari seluruh atau sebagian proyek, termasuk biaya operasional setelah proyek dari sistem yang telah diimplementasikan.

Sedangkan menurut Schniederjans dan Hamaker (2004, p.9) "The investment decisions of allocating all types (i.e., human, monetary, physical) of resources to an MIS". Definisi tersebut dapat diartikan bahwa investasi teknologi adalah suatu keputusan investasi dalam mengalokasikan semua jenis sumber daya (termasuk manusian dan uang) untuk manajemen sistem informasi.

Jadi dapat disimpulkan bahwa investasi TI merupakan kegiatan di mana perusahaan mengambil keputusan untuk mengalokasikan sejumlah biaya yang diperlukan untuk menjalankan proyek yang telah mereka implementasikan.

Bandar Djakarta adalah sebuah restoran yang menyajikan beraneka ragam makanan laut dan terletak di tepi laut kawasan Ancol Timur. Restoran ini berdiri pada tanggal 23 Desember 2001 dengan kapasitas awal hanya sekitar 200 orang. Untuk mendukung kegiatan operasional, diterapkan suatu sistem informasi operasional pada tahun 2004. Kemudian pada tahun 2010 Bandar Djakarta melakukan pengembangan. Sistem ini mendukung kegiatan yang berjalan pada service area, cashier area, dan community program.

Menurut Fitzpatrick (2005, PP.31 - PP.32), proses investasi TI dapat dibagi dalam tiga tahap, yaitu tahap seleksi, kontrol dan evaluasi. Salah satu teknik yang dapat diaplikasikan dalam menilai kelayakan investasi adalah cost benefit analysis. Nita Anggeraini (2008) menuliskan dengan mengutip dari buku (Brzozowska, 2007, Cost Benefit Analysis in Public Project Appraisal) bahwa teknik ini secara luas dikembangkan untuk perencanaan, pendukung keputusan, evaluasi program, evaluasi proposal dan lain sebagainya pada seluruh jenis organisasi.

Penelitian dilakukan untuk mengetahui efektivitas dan efisiensi investasi teknologi informasi pada Restoran Bandar Djakarta, dan mengetahui nilai balik dari investasi teknologi informasi yang diterapkan pada perusahaan. Efektivitas merupakan hubungan antara outcome dan output. Terdapat dua kategori outcome, yaitu perubahan kondisi dan perubahan perilaku. Salah satu contoh perubahan kondisi adalah perbaikan mutu kesehatan masyarakat atau kebersihan air. Sementara itu, contoh perubahan perilaku adalah adanya perubahan sikap para pelaku tindak kriminal sering berjalannya sistem peradilan atau perubahan sikap orang tua dan anak berkat peran dinas sosial dalam mengurangi tindak kekerasan dalam keluarga. Perubahan perilaku lebih sulit diukur daripada perubahan kondisi (Rai, 2008). Sedangkan efisiensi mengandung pengertian perbandingan antara biaya dan hasil (Tangkilisan, 2005). Dituliskan juga oleh Rai (2008) bahwa secara sederhana, efisiensi merupakan perbandingan antara output dan input. 
Ruang lingkup dari penelitian ini adalah pertama, melakukan evaluasi investasi teknologi informasi pada sistem informasi operasional restoran Bandar Djakarta dari sistem lama ke sistem baru yang terdiri dari service area (merupakan sistem yang menangani penginputan nomor meja, daftar menu, mengirim menu yang disorder kebagian kasir dan dapur), cashier area (mengolah perhitungan harga-harga dari menu yang dipesan pelanggan), community program (sistem yang mengumpulkan data diri pelanggan dan adanya community card yang berfungsi untuk diskon di setiap transaksi). Kedua, melakukan evaluasi efektifitas dengan menggunakan metode cost benefit analysis, antara lain PVC (present value of costs), PVB (present value of benefits), NPV (net present value), BCR (benefit cost ratio), ROI (return on investment) dan PP (payback period), sedangkan evaluasi efisiensi menggunakan kuisioner dengan pengukuran skala Likert

Penelitian ini diharapkan dapat memberikan informasi mengenai manfaat investasi teknologi informasi secara finansial menggunakan cost benefit analysis, dan memberikan dukungan pengambilan keputusan mengenai tindak lanjut terhadap investasi tersebut.

\section{METODE}

Selain studi pustaka, penelitian ini juga menerapkan studi lapangan. Tahapan studi lapangan adalah: melakukan wawancara pada pihak-pihak yang terkait, mengumpulkan berbagai data yang diperlukan, melakukan penyebaran kuesioner berkaitan dengan efektifitas dan efisiensi sistem yang sudah ada dimana perhitungan kuesioner dilakukan menggunakan skala likert, dan menggunakan metode Cost Benefit Analysis untuk menghitung evaluasi efektifitas dan efisiensi sistem informasi operasional pada restaurant sea-food tersebut.

\section{Cost/ Benefit Analysis}

Mengacu pada pendapat Schniederjans et al. (2010, PP.144 - PP.158), terdapat lima tahapan dalam melakukan analisis investasi menggunakan cost benefit analysis dapat dilihat pada Gambar 1:

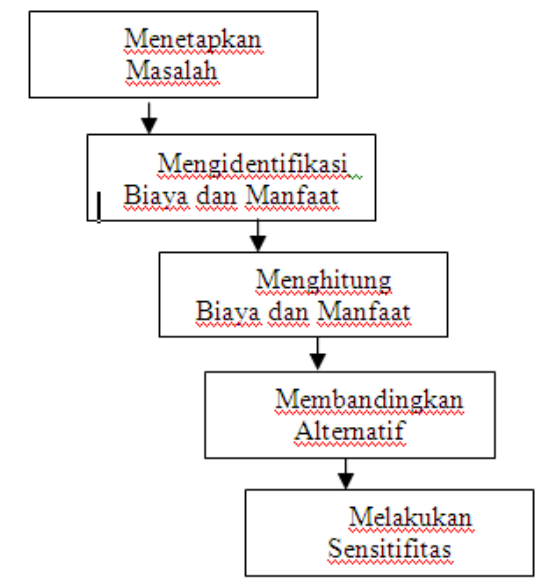

Gambar 1 Tahapan cost benefit analysis

\section{Benefit / Cost Ratio}

Menurut Schniederjans (2010) "The benefit/ cost ratio is the present value of benefits devided by the present value of cost". Definisi tersebut dapat diartikan benefit/ cost ratio adalah nilai sekarang (present value) dari manfaat dibagi dengan nilai sekarang dari biaya dan dihitung sebagai berikut: 


$$
\text { Benefit Cost Ratio }=\frac{\mathrm{PV}=\sum_{t=0}^{n} \frac{\mathrm{B}_{\mathrm{t}}}{(1+\mathrm{r})^{\mathrm{t}}}}{\mathrm{PV}=\sum_{t=0}^{n} \frac{\mathrm{C}_{\mathrm{t}}}{(1+\mathrm{r})^{\mathrm{t}}}}
$$

\section{Payback Period}

Menurut Schniederjans (2010) "Payback period is a common accounting and finance tool used select the alternative that recovers its cost in the shortest amount of time". Definisi tersebut dapat diartikan payback period adalah penghitungan yang biasa digunakan untuk memilih alternatif yang dapat mengembalikan biaya dalam waktu tersingkat.

$$
\text { Payback Period }=\frac{\text { Co }}{C} \times 1 \text { th }
$$

\section{Net Present Value (NPV)}

Menurut Schniederjans (2010) "Net present value is the present value of cash flow minus the initial investment cost". Definisi tersebut dapat diartikan net present value adalah present value dari arus kas dikurangi biaya investasi awal. Suatu teknik analisis yang membandingkan biaya dan manfaat annual discounted dari solusi alternatif. Net Present Value dapat dihitung sebagai berikut:

$$
\mathrm{NPV}=\frac{B_{0}-C_{0}}{(1+\mathrm{r})^{0}}+\frac{B_{1}-C_{1}}{(1+\mathrm{r})^{1}}+\ldots .+\frac{B_{n}-C_{n}}{(1+\mathrm{r})^{\mathrm{n}}}
$$

\section{Profitability Index (PI)}

Menurut Schniederjans (2010), "Profitability index is a ratio that can be used to rank projects when the size of initial investment in mutually exclusive set". Definisi tersebut dapat diartikan PI adalah rasio yang dapat digunakan untuk menentukan tingkatan proyek ketika investasi awal berada pada mutually exclusive set. Profitability index dapat dihitung sebagai berikut:

$$
\mathrm{PI}=\frac{\mathrm{NPV}}{\text { Biaya Investasi }}
$$

\section{Return on Investment (ROI)}

Menurut Schniederjans (2010), "Return on Investment methodology is another technique traditionally used in capital budgeting decisions where the rate of return of an investment is compared to the opportunity cost of capital'. Definisi tersebut dapat diartikan ROI adalah teknik lain yang biasanya digunakan dalam keputusan penganggaran modal di mana tingkat pengembalian investasi dibandingkan dengan biaya peluang modal. Return on investment dapat dihitung sebagai berikut:

$$
\mathrm{ROI}=\frac{\text { Keuntungan }}{\text { Biaya Investasi }} \times 100 \%
$$




\section{Proses Bisnis}

Proses bisnis dimulai saat pelanggan memesan makanan. Pelanggan akan mengisi waiting list, kemudian akan memilih jenis-jenis seafood apa saja yang diinginkan di pasar ikan dan ditimbang serta menentukan menu masakan yang diinginkan. Staf order taker akan membuat nota pesanan makanan dan diberikan kepada pelayan yang akan diantarkan kepada bagian dapur dan bagian kasir. Staf order taker akan memberikan nomor meja kepada pelanggan dan staf guest relation officer (GRO) mengantarkan pelanggan ke lokasi meja. Setelah pelanggan berada di lokasi meja yang ditempatinya, pelayan akan memberikan buku menu dan mencatat nota pesanan minuman. Nota pesanan tersebut akan di-input dalam station dan dikirim ke Bagian kasir dan juga Bagian Minuman (bar). Pesanan yang diterima Bagian minuman akan dicetak. pembuatan minuman tersebut kemudian diproses dan diantarkan kepada pelanggan. Bagian dapur akan memproses makanan sesuai nota pesanan makanan yang telah diterima. Sebelum pesanan makanan diantarkan, Staf checker melakukan pengecekkan pada pesanan tersebut terlebih dahulu. Bagian kasir akan mencetak bill dan diserahkan kepada pelayan. Kemudian pelayan akan memberikan bill kepada Pelanggan dan menerima uang pembayaran yang akan diproses oleh bagian kasir. Pembayaran ini dapat dilakukan dengan tunai dan kartu kredit. Proses ini terangkum dalam Gambar 2.

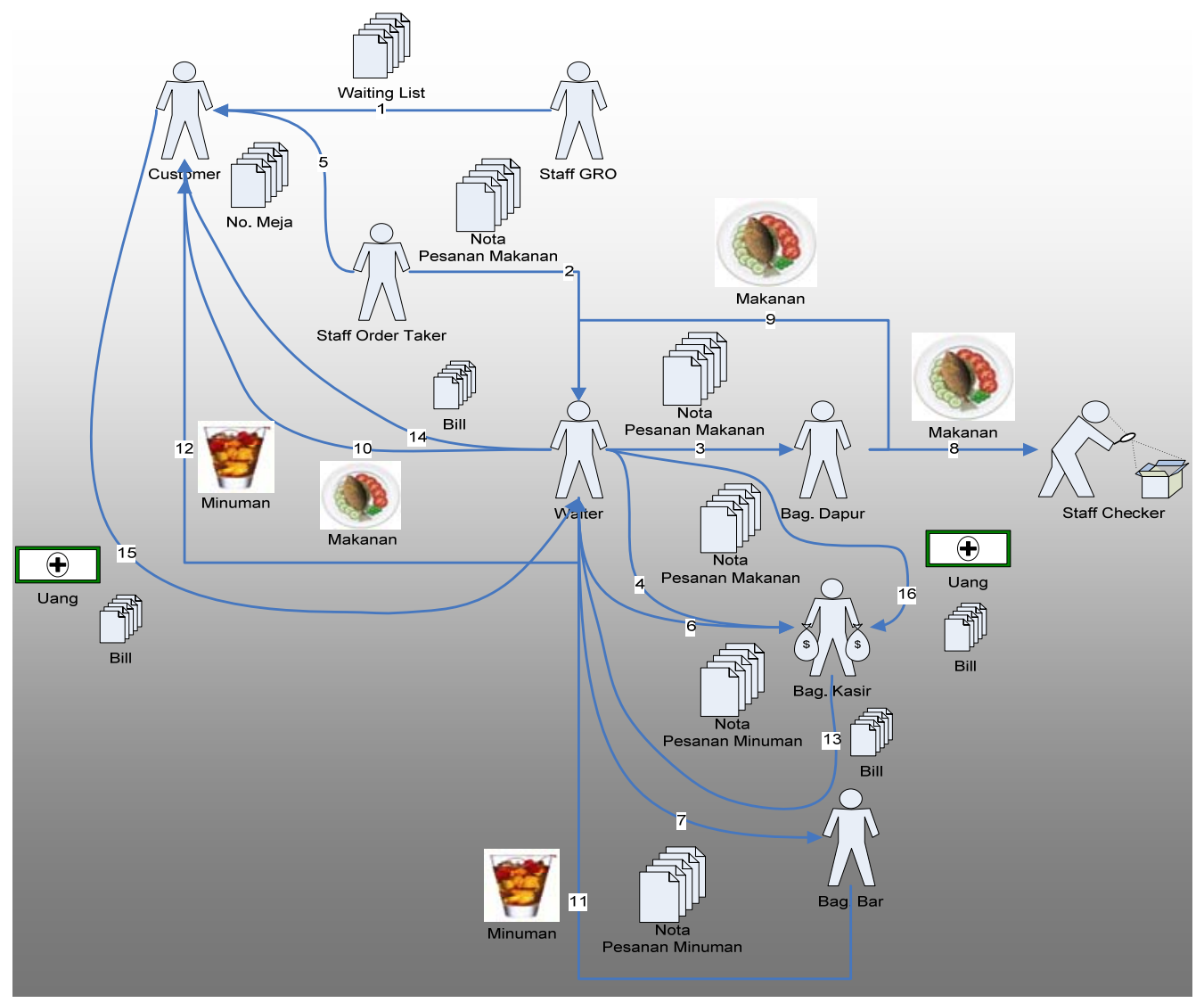

Gambar 2 Rich picture proses bisnis kegiatan operasional

\section{Investasi TI/ SI} berikut ini.

Detail mengenai investasi TI/SI yang sudah berjalan dapat dilihat pada Tabel 1 - Tabel 4 
Table 1Total Investasi Tahun 2004

\begin{tabular}{llcrr}
\hline No. & Deskripsi & Jumlah & Harga Satuan & Total \\
\hline 1. & Paket Hardware & & & $19,573,000$ \\
\hline 2. & Software POS Restoran Full Plus & 1 & $3,600,000$ & $3,600,000$ \\
& Version & & & \\
\hline 3. & Supplies & & & 1,750 \\
& 76mm 2 Ply Paper Roll & 100 & 5,000 & 175,000 \\
& Ribbon Cartridge & 10 & & 50,000 \\
\hline$\quad$ Total & & $23,398,000$ \\
\hline
\end{tabular}

Tabel 2Total Investasi Hardware tahun 2010

\begin{tabular}{|c|c|c|c|c|c|}
\hline No. & Deskripsi & Jumlah & Harga & $\begin{array}{l}\text { Subtotal } \\
\text { (USD) }\end{array}$ & $\begin{array}{l}\text { Subtotal } \\
\text { (IDR) }\end{array}$ \\
\hline 1. & $\begin{array}{l}\text { System Server } \\
\text { Core } 2 \text { Duo Server, 4GB RAM,2x250GB } \\
\text { RAID } 0 \text { SATA HDD }\end{array}$ & 1 & USD 750 & 750 & \\
\hline 2. & $\begin{array}{l}\text { Posifex Integrated Terminal } \\
\text { - } \quad \text { JIVA-5815 Pro Processor Via C-7 } \\
\text { 1.5 Ghz } \\
\text { - } \quad \text { HDD 80GB 512MB DDR Memory } \\
\text { upgradable to 2 Giga } \\
\text { - } \quad \text { With 15.1" TFTLCD, dual back lite } \\
\quad \text { Touch Screen } \\
\text { - } \quad \text { Epson TM-U220D } \\
\text { - } \quad \text { MSR Posiflex } 3 \text { Stripe }\end{array}$ & 10 & $\begin{array}{r}\text { USD } \\
1,650\end{array}$ & 16,500 & \\
\hline 3. & $\begin{array}{l}\text { UPS Untuk Terminal } \\
600 \mathrm{kVa}, 8 \text { Terminal, } 6 \text { Printer Bar, } 2 \text { Backup }\end{array}$ & 16 & $\begin{array}{r}\text { IDR } \\
650,000\end{array}$ & & $10.400,000$ \\
\hline 4. & $\begin{array}{l}\text { Epson TM-U220 untuk Bar } \\
\text { Printer Bar dengan Print Server } \\
\text { - } 4 \text { Printer Bar } \\
\text { - } 2 \text { Printer Mini Bar } \\
\text { - } 2 \text { Printer Backup }\end{array}$ & 8 & USD 311 & 2,488 & \\
\hline 5. & $\begin{aligned} \text { Network } & \text { Switch } \\
- & 3 \text { Point } \\
\text { - } & 2 \text { Backup }\end{aligned}$ & 5 & USD 36 & 180 & \\
\hline 6. & Windows Embedded OS & 10 & USD 137 & 1,370 & \\
\hline \multicolumn{2}{|c|}{ TOTAL } & & & USD 21,288 & $\begin{array}{r}\text { IDR } \\
10,400,000\end{array}$ \\
\hline
\end{tabular}

Tabel 3 Biaya Operasional Bandar Djakarta Tahun 2004 - 2009 (Rupiah)

\begin{tabular}{clrrrrrr}
\hline No & Keterangan & \multicolumn{1}{c}{$\mathbf{2 0 0 4}$} & \multicolumn{2}{c}{$\mathbf{2 0 0 5}$} & \multicolumn{2}{c}{$\mathbf{2 0 0 6}$} & \multicolumn{2}{c}{$\mathbf{2 0 0 7}$} & \multicolumn{2}{c}{$\mathbf{2 0 0 8}$} & $\mathbf{2 0 0 9}$ \\
\hline 1 & Gaji Pegawai & $2,014,650,000$ & $2,562,634,800$ & $3,440,220,000$ & $4,863,024,000$ & $5,252,061,600$ & $5,777,271,000$ \\
\hline 2 & $\begin{array}{l}\text { Biaya Listrik, } \\
\text { Telepon, dan Air }\end{array}$ & $58,700,000$ & $71,700,000$ & $96,525,200$ & $138,149,400$ & $211,925,400$ & $227,338,500$ \\
\hline 3 & Penyusutan & $117,400,000$ & $143,400,000$ & $193,050,400$ & $276,298,800$ & $423,850,800$ & $454,677,000$ \\
\hline
\end{tabular}




\begin{tabular}{clrrrrrr}
\hline \multicolumn{2}{l}{ aktiva tetap } & & & & & \\
\hline 4 & $\begin{array}{l}\text { Peralatan dan } \\
\text { Perlengkapan } \\
\text { Kantor }\end{array}$ & $234,800,000$ & $286,800,000$ & $386,100,800$ & $552,597,600$ & $847,701,600$ & $909,354,000$ \\
& & & & & & \\
\hline 5 & Lain - lain & $293,500,000$ & $358,500,000$ & $482,626,000$ & $690,747,000$ & $1,059,627,000$ & $1,136,692,500$ \\
\hline Total & $\mathbf{3 , 1 9 9 , 0 5 0 , 0 0 0}$ & $\mathbf{3 , 7 8 3 , 0 3 4 , 8 0 0}$ & $\mathbf{5 , 0 7 8 , 5 2 2 , 4 0 0}$ & $\mathbf{7 , 2 4 0 , 8 1 6 , 8 0 0}$ & $\mathbf{8 , 8 7 5 , 1 6 6 , 4 0 0}$ & $\mathbf{9 , 7 0 5 , 3 3 3 , 0 0 0}$ \\
\hline
\end{tabular}

Tabel 4Biaya Operasional Bandar Djakarta Tahun 2010 - 2011 (Rupiah)

\begin{tabular}{llrr}
\hline No & \multicolumn{1}{c}{ Keterangan } & \multicolumn{1}{c}{$\mathbf{2 0 1 0}$} & \multicolumn{1}{c}{$\mathbf{2 0 1 1}$} \\
\hline 1 & Gaji Pegawai & $6,708,054,000$ & $7,740,000,000$ \\
2 & Biaya Listrik, Telepon, dan Air & $1,412,081,400$ & $1,465,500,000$ \\
3 & Penyusutan aktiva tetap & 470693800 & 488500000 \\
4 & Biaya Pelatihan & $1,000,000$ & \\
5 & Peralatan dan Perlengkapan Kantor & $941,387,600$ & $977,000,000$ \\
6 & Lain - lain & $1,176,734,500$ & $1,221,250,000$ \\
\hline Total & $\mathbf{1 2 , 4 0 9 , 9 5 1 , 3 0 0}$ & $\mathbf{1 3 , 7 6 2 , 2 5 0 , 0 0 0}$ \\
\hline
\end{tabular}

\section{Evaluasi}

Evaluasi efektivitas investasi SI operasional sistem lama (Tahun 2004-2009) ditampilkan pada

Tabel 5.

Tabel 5 Biaya dan Manfaat SI Tahun 2004-2006 (Rupiah)

\begin{tabular}{lcccccc}
\hline & $\mathbf{2 0 0 4}$ & $\mathbf{2 0 0 5}$ & $\mathbf{2 0 0 6}$ & $\mathbf{2 0 0 7}$ & $\mathbf{2 0 0 8}$ & $\mathbf{2 0 0 9}$ \\
\hline Biaya dan Manfaat: & & & & & \\
\hline Hardware & $19,573,000$ & & & & & \\
\hline Networking & & & & & & \\
\hline Software & $3,600,000$ & & & & & \\
\hline Supplies & 225,000 & 275,000 & 325,500 & 500,000 & 825,000 & 900,000 \\
\hline Biaya lain-lain & $3,199,050,000$ & $3,783,034,800$ & $5,078,522,400$ & $7,240,816,800$ & $8,875,166,400$ & $9,705,333,000$ \\
& & & & & & \\
\hline Total Biaya & $3,199,275,000$ & $3,783,309,800$ & $5,078,847,900$ & $7,241,316,800$ & $8,875,991,400$ & $9,706,233,000$ \\
\hline Pendapatan & & $20,340,000,000$ & $27,305,040,000$ & $39,629,880,000$ & $60,385,080,000$ & $65,467,700,000$
\end{tabular}

Biaya dan manfaat dari Tabel 5 menjelaskan bahwa dengan menggunakan sistem lama, biaya dan pendapatan dari tahun 2004 sampai 2009 naik tidak terlalu besar.

Evaluasi efektivitas investasi SI operasional pada sistem baru (tahun 2010-2011) adalah sebagai berikut (Tabel 6): 
Tabel 6 Biaya dan Manfaat SI Tahun 2010-2011

\begin{tabular}{|c|c|c|}
\hline & 2010 & 2011 \\
\hline \multicolumn{3}{|c|}{ Biaya dan Manfaat: } \\
\hline Hardware & $208,378,400$ & \\
\hline Networking & $26,000,000$ & \\
\hline Software & $42,900,000$ & \\
\hline Supplies & $3,150,000$ & $3,275,000$ \\
\hline Biaya lain-lain & $12,409,951,300$ & $13,762,250,000$ \\
\hline Total Biaya & $12,690,379,700$ & $13,765,525,000$ \\
\hline Pendapatan & & $70,850,000,000$ \\
\hline
\end{tabular}

Tabel 6 menyatakan bahwa dengan menggunakan sistem baru, biaya tahun 2010 dan 2011 mengalami kenaikan yang kecil, sedangkan pendapatannya mengalami kenaikan yang besar.

\section{Present Value (PV) of Cost and Benefits}

PV of cost dihitung dengan rumus berikut:

$$
\mathbf{P V}=\sum_{t=0}^{n} \frac{A^{t}}{(1+r)^{t}}
$$

PV of cost tahun $2004=$ Rp.3.199.275.000

PV of cost tahun $2005=$ Rp.2.045.032.324

PV of cost tahun $2006=$ Rp.4.030.811.673

PV of cost tahun $2007=$ Rp.1.191.321.395

PV of cost tahun $2008=$ Rp.718.144.410,4

PV of cost tahun $2009=$ Rp.736.167.525,5

Jadi, $\sum$ PV of costs sistem lama $=34,403,142,741$ (investasi layak dilakukan)

PV of cost tahun $2010=$ Rp.12.3690.379.700

PV of cost tahun $2011=$ Rp.7.440.824.324.

Jadi, $\sum P V$ of cost sistem baru= 20,131,204,024 (investasi layak dilakukan)

PV of benefits dihitung dengan rumus:

$$
\mathrm{PV}=\sum_{t=0}^{n} \frac{A^{t}}{(1+r)^{t}}
$$

PV of benefits tahun 2005

PV of benefits tahun 2006

$=$ Rp. $10,994,594,595$

$=$ Rp.21,670,559,174

PV of benefits tahun 2007

$=$ Rp. $6,519,798,158$

PV of benefits tahun 2008

$=$ Rp. $4,885,674,818$

PV of benefits tahun 2009

$=$ Rp. $4,965,386,130$

PV of benefits tahun 2011

$=$ Rp.38.297.297.297

\section{Benefit/cost ratio}

Benefit/cost ratio adalah present value of benefits dibagi dengan present value of costs dengan rumus sebagai berikut: 
$\begin{aligned} \text { Benefit/Cost Ratio sistem lama } & =\frac{\sum_{t=0}^{n} \frac{B_{t}}{(1+r)^{t}}}{\sum_{t=0}^{n} \frac{C_{t}}{(1+r)^{t}}} \\ & =\frac{49,036,012,875}{11,920,752,328} \\ & =0.24 \\ \text { Benefit/Cost Ratio sistem baru }= & \frac{\sum_{t=0}^{n} \frac{B_{t}}{(1+r)^{t}}}{\sum_{t=0}^{n} \frac{C_{t}}{(1+r)^{t}}} \\ & =\frac{38,297,297,297}{814,490,018.7} \\ & =1.9\end{aligned}$

Net Present Value (NPV)

NPV tahun $2004=-3199275000$

NPV tahun $2005=8949562270$

NPV $2006=17639747501$

NPV tahun $2007=5328476763$

NPV tahun $2008=4167530408$

NPV tahun $2009=4229218604$

$\sum \mathrm{NPV}$ sistem lama $=\quad 37,115,260,547$ (layak dilakukan)

NPV tahun $2009=-12.690 .379 .700$

NPV tahun $2010=30,856,472,973$

Maka, NPV sistem baru = 18,166,093,273 (layak dilakukan)

\section{Return on Investment (ROI)}

$\begin{array}{lll}\text { ROI } & = & \frac{\text { Pendapatan Bersih }}{\text { Biaya Investasi }} \times 100 \% \\ \text { ROI sistem lama } & = & \frac{175,242,726,100}{23,398,000} \times \mathbf{1 0 0} \% \\ & = & 748964.553 \% \text { (layak dilakukan) } \\ \text { ROI sistem baru } & = & \frac{44,394,095,300}{280,428,400} \times \mathbf{1 0 0} \% \\ & = & 158.3 \%\end{array}$

Dari hasil perhitungan ROI diatas dengan sistem yang baru dapat disimpulkan return on investment dari tahun 2010-2011 adalah $-158.3 \%$, maka investasi tersebut belum dapat kembali modal pada tahun pertama.

\section{Payback Periods}

Payback period untuk sistem lama ditampilkan pada Tabel 7. 
Tabel 7 Data Payback Periods Tahun 2004-2009

\begin{tabular}{lrr}
\hline & Cash Flow Year $\boldsymbol{n}$ & Sum of cash flow \\
\hline Initial Cost (2004) & $8,788,548,000$ & \\
\hline \multirow{2}{*}{2005} & $16,556,690,200$ & $16,556,690,200$ \\
\hline
\end{tabular}

Berdasarkan tabel 7 di atas, terlihat bahwa biaya awal investasi teknologi informasi yang dikeluarkan senilai Rp.8,788,548,000 dengan jangka pengembalian satu tahun. Dengan demikian, investasi ini memberikan dampak yang baik bagi perusahaan. Payback period untuk sistem baru ditampilkan pada Tabel 8 .

Tabel 8 Data Payback Periods Tahun 2010-2011

\begin{tabular}{lrr}
\hline & Cash Flow Year $\boldsymbol{n}$ & \multicolumn{1}{c}{ Sum of cash flow } \\
\hline Initial Cost (2010) & $35,231,110,400$ & \\
\hline 2011 & $44,394,095,300$ & $44,394,095,300$
\end{tabular}

Berdasarkan tabel 8 di atas, terlihat bahwa biaya investasi IT pada tahun 2010 dengan sistem yang baru mengeluarkan senilai Rp.35,231,110,400 dengan jangka pengembalian yaitu satu tahun.

\section{Evaluasi berdasarkan Kuesioner}

Berikut adalah kusioner yang telah dibagikan kepada 30 responden yang berhubungan langsung dengan sistem informasi operasional (Tabel 9). Responden diberikan pertanyaan bagaimana tangapannya terhadap penggunaan sistem informasi operasional baru (Penghitungan yang dilakukan adalah dengan menggunakan skala Likert.

Tabel 9 Tabel Kuisioner

\begin{tabular}{|c|c|c|c|c|c|}
\hline Pertanyaan & SS & $\mathbf{S}$ & RR & TS & STS \\
\hline 1. Apakah sistem memudahkan kegiatan operasional? & & & & & \\
\hline 2. Apakah sistem mudah dioperasikan (user friendly)? & & & & & \\
\hline $\begin{array}{l}\text { 3. Apakah sistem yang berjalan berpengaruh dalam citra } \\
\text { perusahaan? }\end{array}$ & & & & & \\
\hline 4. Apakah sistem memberikan informasi yang akurat? & & & & & \\
\hline 5. Apakah informasi diberikan tepat waktu dan up-to-date? & & & & & \\
\hline
\end{tabular}

Keterangan:

$$
\begin{array}{ll}
\mathrm{SS} & =\text { Sangat Setuju } \\
\mathrm{S} & =\text { Setuju } \\
\mathrm{RR} & =\text { Ragu-ragu } \\
\mathrm{TS} & =\text { Tidak Setuju } \\
\text { STS } & =\text { Sangat Tidak Setuju }
\end{array}
$$

Hasil jawaban kuisioner dikali dengan poin skala Likert kemudian dipersentasekan untuk diproyeksikan dalam bentuk diagram (Gambar 3) dengan rumus: 
di mana

((total tanggapan $x *$ poin skala Likert $) /$ total poin skala likert $) * 100 \%$

total poin skala likert $=\sum($ total tanggapan $x *$ poin skala Likert $)=(56 * 5)+(83 * 4)+(8 * 3)+(3 * 2)=$ 642.

Maka hasilnya:

$\mathrm{SS}$ (sangat setuju) $\quad=\quad((56 * 5) / 642) * 100 \%=43.6 \%$

$\mathrm{S}$ (setuju) $\quad=\quad((83 * 4) / 642) * 100 \%=51.7 \%$

RR (Netral) $\quad=\quad((8 * 3) / 642) * 100 \%=3.73 \%$

TS (Tidak Setuju $\quad=\quad((3 * 2) / 642) * 100 \%=0.93 \%$

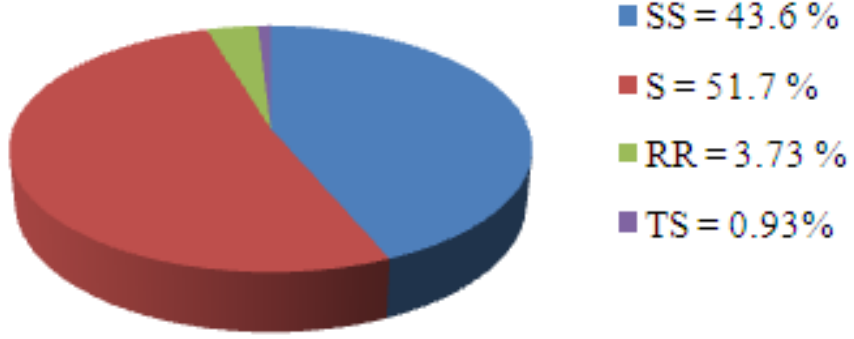

Gambar 3 Grafik hasil perhitungan kuesioner

Berdasarkan Gambar 3, terlihat tingginya tanggapan setuju (positif). Dari penggambaran tersebut, dapat disimpulkan bahwa sistem informasi operasional yang digunakan telah efisien. Berdasarkan wawancara dengan pihak Bandar Djakarta (head of business), sistem informasi pada tahun 2004 cukup murah tapi hanya dapat menangani bagian kasir serta rendahnya tingkat keamanan dikarenakan tidak adanya pembatasan akses data. Sedangkan sistem informasi pada tahun 2010 sudah menangani tiga bagian (kasir, layanan, dan program komunitas). Berdasarkan kuisioner, dapat disimpulkan bahwa perusahaan mendapatkan dukungan kemudahan dalam beroperasi tapi tidak menyulitkan pengguna, citra perusahaan semakin baik, serta data lebih akurat dan tepat waktu.

\section{PENUTUP}

Berdasarkan hasil penelitian yang dilakukan terhadap investasi teknologi informasi Bandar Djakarta dengan menggunakan metode cost benefit analysis dan kuisioner dengan pengukuran skala Likert untuk mengetahui efektivitas dan efisiensi investasi teknologi informasi pada Bandar Djakarta, simpulan yang didapat adalah tingkat pengembalian terhadap Investasi teknologi informasi yang dilakukan pada tahun 2004 dan 2010 terjadi dalam satu tahun, tingkat kebutuhan pegawai ketika berinvestasi pada tahun 2010. Hal ini telah memberikan penghematan sebesar $0.09 \%$. Berdasarkan hasil kuisioner yang telah dibagikan kepada user,dapat disimpulkan bahwa Investasi teknologi informasi yang dijalankan dalam sistem operasional telah memberikan kemudahan operasional yang dijalankan oleh user. Hal ini menunjukkan investasi teknologi informasi tersebut efisien.

Saran yang dapat diberikan kepada perusahaan sebagai berikut: (1) melakukan back up data secara rutin, sehingga tidak terjadi penumpukan data yang mengakibatkan sistem tersebut tidak dapat melakukan transaksi (berdasarkan kejadian di bulan November 2011); (2) sebaiknya ketika pelanggan mencapai minimum transaksi berdasarkan yang disepakati oleh pihak perusahaan, pelayan akan menawarkan Community Card untuk mendukung community program sehingga program tersebut dapat lebih disosialisasikan dan meningkatkan kepuasan pelanggan dengan adanya kelebihankelebihan yang ditawarkan 


\section{DAFTAR PUSTAKA}

Bandi. (2006). Pengaruh Respon Perusahaan dalam Investasi teknologi informasi terhadap Kinerja Perusahaan: Strategi Bisnis Kematangan teknologi informasi, dan Ukuran Perusahaan sebagai variable Anteseden. Diakses dari http://www.scribd.com/doc/13065865

Fitzpatrick, E.W. (2005). Planning and Implementing IT Portfolio Management: Maximizing The Return on Information Technology Investments. Gaithersburg-Marryland: IT Economics Corporation.

Rai, Gusti Agung. (2008). Audit kinerja pada skctor public. Jakarta: Penerbit Salemba Empat.

Scniederjans, M.J., Hamaker, J.L., \& Scniederjans, A.M. (2010). Information Technology Investment: Decision-Making Methodology ( $2^{\text {nd }}$ ed.). Singapore: World Scientific Publishing.

Tangkilisan, Hessel Nogi S. (2005). Manajemen Publik. Jakarta: Grasindo. 